\title{
Health status of Polychrus gutturosus based on physical examination, hematology and biochemistry parameters in Costa Rica
}

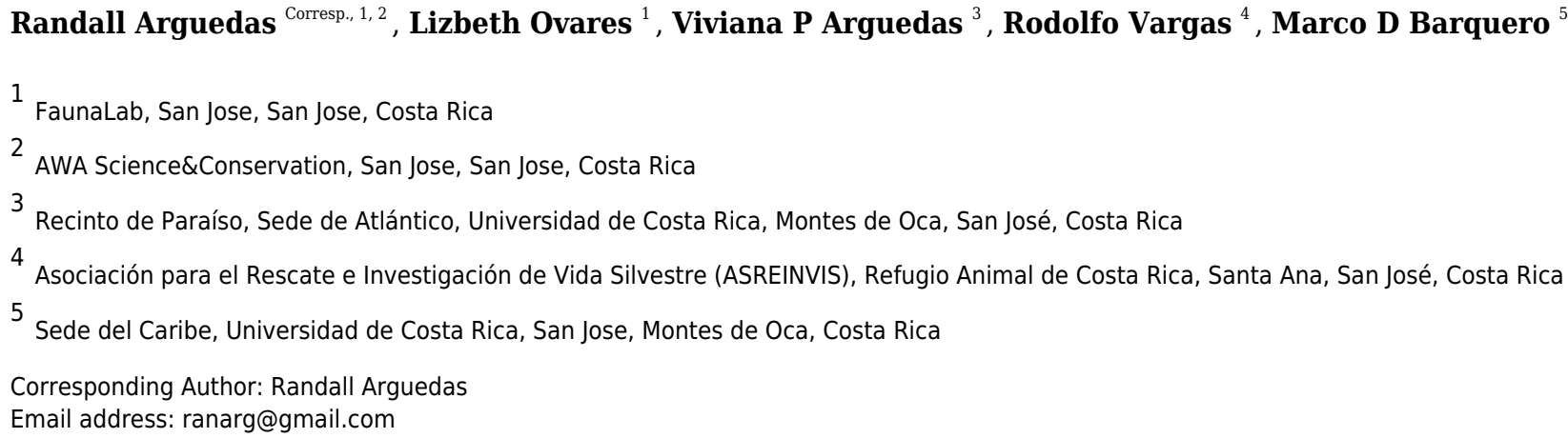

Studies evaluating the health status and characteristics of free-ranging wildlife populations are scarce or absent for most species. Saurian health assessments are usually performed in species that have conservation issues or that are kept in captivity. The Berthold's bush anole (Polychrus guturossus) is one of eight species belonging to the genus Polychrus, the only representative of the family Polychrotidae. Only a handful of studies have been reported concerning these lizard's morphological variation, ecology, and natural history, probably because $P$. gutturosus is a canopy dweller and it can be difficult to locate individuals. It is believed that deforestation and habitat modification could pose a threat for this species, although to date no health assessment has been done. The aim of this study was to generate health baseline data on $P$. gutturosus. Forty Berthold's bush anoles (20 males and 20 females) were sampled at the Pacific versant in Costa Rica, where physical examination, skin and cloacal temperatures, and blood samples were obtained from individuals immediately after capture. Animals from the studied population were all healthy (body condition 2.5-3.0/5.0). No lesions or ectoparasites were detected, but hemoparasites were found in nine individuals. Hematological and biochemical values were obtained, and the morphology of leukocytes were found to be similar to other iguanians. A positive correlation was found between the tissue enzymes Aspartate amino transferase (AST) and Creatinine kinase (CK) and a negative correlation was found between skin and cloacal temperatures and AST and CK. There were positive correlations between female weight and total protein, Calcium, and the Calcium and Phosphorus ratio. No significant inter-sex differences were found in biochemical values, despite females being larger than males. This is the first health assessment performed on a free-ranging canopy dwelling 
lizard. These findings provide baseline data that may be useful for future monitoring if the species faces changes in health status due to anthropogenic causes or natural disturbances. 
1 Health status of Polychrus gutturosus based on

2 physical examination, hematology and biochemistry

3 parameters in Costa Rica

4

5

6

7

8

Randall Arguedas ${ }^{1,2}$, Lizbeth Ovares ${ }^{2}$, Viviana P. Arguedas ${ }^{3}$, Rodolfo Vargas ${ }^{4}$, Marco D. Barquero $^{5}$

${ }^{1}$ AWÁ Science \& Conservation, San José, San José, Costa Rica

${ }^{2}$ FaunaLab, San José, San José, Costa Rica

${ }^{3}$ Recinto de Paraíso, Sede de Atlántico, Universidad de Costa Rica, Montes de Oca, San José, Costa Rica

${ }^{4}$ Refugio Animal de Costa Rica, Asociación para el Rescate e Investigación de Vida Silvestre (ASREINVIS), Santa Ana, San José, Costa Rica

${ }^{5}$ Sede del Caribe, Universidad de Costa Rica Montes de Oca, San José, Costa Rica

Corresponding Author:

Randall Arguedas ${ }^{1,2}$

AWÁ Science \& Conservation, San José, San José, Costa Rica

FaunaLab, San José, San José, Costa Rica

Email address: ranarg@gmail.com

\section{Abstract}

Studies evaluating the health status and characteristics of free-ranging wildlife populations are scarce or absent for most species. Saurian health assessments are usually performed in species that have conservation issues or that are kept in captivity. The Berthold's bush anole (Polychrus guturossus) is one of eight species belonging to the genus Polychrus, the only representative of the family Polychrotidae. Only a handful of studies have been reported concerning these lizard's morphological variation, ecology, and natural history, probably because $P$. gutturosus is a canopy dweller and it can be difficult to locate individuals. It is believed that deforestation and habitat modification could pose a threat for this species, although to date no health assessment has been done. The aim of this study was to generate health baseline data on P. gutturosus. Forty Berthold's bush anoles (20 males and 20 females) were sampled at the Pacific versant in Costa Rica, where physical examination, skin and cloacal temperatures, and blood samples were obtained from individuals immediately after capture. Animals from the studied population were all healthy (body condition 2.5-3.0/5.0). No lesions or ectoparasites were detected, but hemoparasites were found in nine individuals. Hematological and biochemical values were obtained, and the morphology of leukocytes were found to be similar to other iguanians. A positive correlation was found between the tissue enzymes Aspartate amino transferase (AST) 
40

41

42

43

44

45

46

47

48

49

50

51

52

53

54

55

56

57

58

59

60

61

62

63

64

65

66

67

68

69

70

71

72

73

74

75

76

77

78

79

and Creatinine kinase (CK) and a negative correlation was found between skin and cloacal temperatures and AST and CK. There were positive correlations between female weight and total protein, Calcium, and the Calcium and Phosphorus ratio. No significant inter-sex differences were found in biochemical values, despite females being larger than males. This is the first health assessment performed on a free-ranging canopy dwelling lizard. These findings provide baseline data that may be useful for future monitoring if the species faces changes in health status due to anthropogenic causes or natural disturbances.

\section{Introduction}

Population declines due to anthropogenic causes such as habitat fragmentation, pollution, invasive species, and global climate change, are widespread (Sinervo et al., 2010; Brusch, Taylor $\&$ Whitfield, 2015). One way to understand how wild animals are impacted by and respond to these environmental stressors is through health assessments (Altizer et al., 2013). Hence, the quantification of hematological and biochemical parameters can be a valuable tool for assessing and monitoring the health and resilience of wild populations (Stacy, Alleman \& Sayler, 2011; Campbell, 2014; Maceda-Veiga et al., 2015).

Health assessments are useful when baseline data on normal health parameter values from a clinically robust population are available (Valle et al., 2018). Therefore, it is important to assess the health of wild species, especially populations that have never been surveyed (Valle et al., 2018). This information helps to identify potential effects of disease, injury, pollutants, or other changing environmental conditions that would be difficult to understand without knowledge of normal species-specific variations in hematological and biochemical variables (Smyth et al., 2014; Lewbart et al., 2015). Performing health evaluations on wildlife populations is being utilized more commonly by conservationists (Mathews et al., 2006) and has become a proactive management approach that allows further conservation actions to be taken (Madliger et al., 2017). For example, Henen, Hofmeyr \& Baard (2013) found that confiscated adult tortoises showed poorer body condition and lower hematological values than wild ones, while Mathews et al. (2006) found that water voles (Arvicola terrestris) with better body condition and higher hematological values had greater survival probability when reintroduced into the wild.

Studies evaluating the health status and characteristics of free-ranging populations are, however, scarce or absent for most species, especially those that are rarely seen in the wild (Bell \& Donnelly 2006; Whitfield et al., 2007; Dallwig et al., 2011). In lizards, health assessments reported in the literature have usually been done on species that are threatened (Alberts et al., 1998; Espinosa-Avilés, Salomón-Soto \& Morales-Martínez, 2008; McEntire et al., 2018), endemic (Lewbart et al., 2015; Arguedas et al., 2018), or kept in captivity (Ellman, 1997; Mayer et al., 2005; Laube et al., 2016), providing information on the survival of species with conservation issues. However, free-ranging species with no apparent threats have generally not been evaluated as well.

The Berthold's bush anole (Polychrus guturossus) is one of eight species belonging to the genus Polychrus and the only representative of the family Polychrotidae in Middle America. 
80

81

82

83

84

85

86

87

88

89

90

91

92

93

94

95

96

97

98

99

100

101

102

103

104

105

106

107

108

109

110

111

112

113

114

115

116

117

118

119

This is a moderately large, diurnal lizard that is distinguished by its bright green body coloration and extremely long tail (over three times the length of the head and body) (Savage, 2002). The species is sexually dimorphic, with females being larger than males (Savage, 2002; Koch et al., 2011) and females having green eyelids, while males have yellow eyelids. The species ranges from Honduras to northwestern Ecuador, apparently restricted to moist and wet forests (Savage, 2002; Leenders, 2019). Despite its large distribution, only a handful studies have been carried out concerning its morphological variation, ecology, and natural history (Taylor, 1956; Roberts, 1997; Koch et al., 2011; Gómez-Hoyos et al., 2015; Bringsøe, Alfaro Sánchez \& Hansen, 2016; Ruiz, Gutiérrez \& Flóres Rocha, 2016). P. gutturosus is a canopy dweller and its body coloration makes it difficult to locate individuals during daylight hours. It is believed that deforestation and habitat modification could pose a threat for this species (Acosta Chaves et al., 2017), although no health assessment has ever been done and population status is unknown.

Health assessments of wildlife in Costa Rica are rare. To our knowledge, health evaluations of free-ranging species have been performed on 20 mammals (Schinnerl et al., 2011; Hagnauer Barrantes, 2012; Bernal-Valle, Jiménez-Soto \& Meneses-Guevara, 2020) and only one reptile (green basilisk, Basiliscus plumifrons, Dallwig et al., 2011). Therefore, our aim is to generate data to improve our knowledge of the health status of more Costa Rican reptiles, by providing baseline data on a wild population of the unique lizard species (P. gutturosus). The following baseline data was included: (1) body temperature and weight, (2) presence of ectoparasites and external abnormalities through physical examination, and (3) hematological and biochemical values. Most of our knowledge on $P$. gutturosus comes from museum specimens (Savage, 2002; Koch et al., 2011) and sporadic observations of individuals in the field (Gómez-Hoyos et al., 2015; Bringsøe, Alfaro Sánchez \& Hansen, 2016; Ruiz, Gutiérrez \& Flóres Rocha, 2016). Therefore, this is the first long-term, empirical study on free-ranging P. gutturosus and one of the few studies overall that has been carried out on a species inhabiting the forest canopy. Our data was also compared to similar information previously published for close relatives of $P$. gutturosus.

\section{Materials \& Methods}

\section{Ethics statement}

All research methods were authorized by Costa Rica's National System of Conservation Areas (SINAC) under permit numbers SINAC-ACC-PI-R-102-2018 and SINAC-ACC-257-2018.

\section{Animal collection and handling}

A total of 40 adult individuals (20 males and 20 females) were collected from October 2018 to May 2019, carrying out one field trip per month. Lizards were surveyed along a public, dirt road at El Rodeo (Cascante-Marín, 2012), Ciudad Colón, San José, Costa Rica (Fig. 1). The area has an irregular topography ranging from 400 to 1016 meters above sea level (masl) and with an annual average temperature of $23.4^{\circ} \mathrm{C}$ and an annual average rainfall of $2467 \mathrm{~mm}$ (Cascante- 
120 Marín, 2012). Two seasons are evident, a rainy season from May to October and a dry season

121

122

123

124

125

126

127

128

129

130

131

132

133

134

135

136

137

138

139

140

141

142

143

144

145

146

147

148

149

150

151

152

153

154

155

156

157

158

159

from December to March, with two transitional months (November and April) (Cascante-Marín, 2012). The area of El Rodeo shows a landscape composed of pastureland and agricultural and urban zones (Fig. 1), although the road sampled was surrounded by bushes, shrubs and trees on both sides. The lizards were searched for only on such shrubs and trees at night, since resting animals are easier to spot. Animals were located between 560 and 754 masl and air temperatures ranged from 21.2 to $27.7^{\circ} \mathrm{C}$.

Once an individual was observed, the skin temperature at the resting site was measured using a digital laser infrared thermometer gun (Nubee ${ }^{\circledR}$, NUB8550AT model). The lizards were then hand-caught from shrubs or trees and taken to a workstation at the temporary mobile field laboratory approximately 5 to $10 \mathrm{~m}$ from the collection site. A J/K/T/E thermocouple thermometer (Professional Instruments ${ }^{\circledR}, 1312$ model) was used to measure the lizard's cloacal body temperature, which was taken by inserting the K probe into the cloaca, approximately 1-2 min after capture. A blood sample was taken after the temperature was measured. The process from catching the animal to collecting its temperature and blood lasted about $12 \mathrm{~min}$.

\section{Physical examination and tagging}

The individual was placed in a cloth bag and weighed on a digital scale (to the nearest $0.1 \mathrm{~g}$ ). Afterwards, the lizard was examined for obvious abnormalities or lesions. Physical examinations were performed according to Divers (2019). Oral cavity inspection was easily performed since they kept their mouths open as a defense mechanism. Any external parasites found on the skin were noted and females were gently palpated to detect if they were gravid (feeling for palpable eggs). The body condition was assessed on a scale of 1-5; 1 being emaciated, 2 underweight, 3 normal, 4 overweight, 5 obese (Divers, 2019). After physical examination, a blood sample was collected and each anole was measured to determine snout-vent length (SVL), and then tagged subcutaneously in the left inguinal region (https:/www.wsava.org/Guidelines/MicrochipIdentification-Guidelines) with a Biomark ${ }^{\circledR}$ HPT12 radio frequency identification tag and released back where it was collected.

\section{Hematology and biochemistry analyses}

Each lizard was manually restrained and $0.2-0.4 \mathrm{ml}$ of blood was drawn from the ventral coccygeal vein. If two attempts to collect blood from the tail were unsuccessful, then blood was taken from the jugular vein. Blood sampling time varied between 3-5 min. For blood draws, a heparinized 30 -gauge needle attached to a $1.0 \mathrm{ml}$ syringe was used. Two blood films were immediately made on clean glass microscope slides and then the rest of the sample from the syringe was placed in a $0.5 \mathrm{ml}$ Eppendorf ${ }^{\circledR}$ tube. All samples were taken to the laboratory the same night and stored at $4{ }^{\circ} \mathrm{C}$ to be processed the following day. Red blood cell (RBC), white blood cell (WBC) and thrombocyte count (TC) were performed using the standard method of a Natt and Herrick solution (1/200) on a Boeco® Neubauer Improved chamber. Packed cell volume (PCV) was determined using high-speed centrifugation (Digisystem ${ }^{\circledR}$ Laboratory

Peer) reviewing PDF | (2020:10:53394:1:1:NEW 3 Dec 2020) 
160

161

162

163

164

165

166

167

168

169

170

171

172

173

174

175

176

177

178

179

180

181

182

183

184

185

186

187

188

189

190

191

192

193

194

195

196

197

198

199

Instruments Inc.) of blood-filled microhematocrit tubes. Differential white blood cells were obtained by examining a peripheral smear stained with Diff-Quick ${ }^{\circledR}$ stain (Campbell, 2014). Polychromatophil percentage was determined by counting the number of polychromatophils among 1000 erythrocytes.

Total proteins were obtained by means of a clinical refractometer (REC-200ATC ${ }^{2}$, RETK-70 model) using plasma from the microhematocrit tube. Biochemical parameters such as aspartate aminotransferase (AST), albumin (Alb), calcium (Ca), cholesterol (Chol), creatinine kinase $(\mathrm{CK})$, glucose, phosphorus $(\mathrm{P})$ and uric acid (UA) were measured with a Roche ${ }^{\circledR}$ analyzer (Cobas c111 model) following the company's instructions.

\section{Comparison with close relatives}

Literature was reviewed for similar hematology and biochemistry information published on close relatives of the Berthold's bush anole. The review focused on the infraorder Iguania, which includes Polychrus gutturosus, according to the phylogeny proposed by Pyron, Burbrink \& Wiens (2013). Twenty-nine papers were found (see supplementary data) corresponding to eight of the 14 families that make up Iguania, from which the mean and standard deviation (or range, when SD was not reported) of hematological and biochemical parameters of free-ranging individuals was obtained. This information was used to place the physiological values generated for P. gutturosus within a phylogenetic context.

\section{Statistical analyses}

The mean, standard deviation, range, and 95\% confidence intervals for all blood parameters were calculated. Differences in weight, biochemistry and hematological values between the sexes were examined using t-tests. Differences between animals infected with hemoparasites and noninfected animals in terms of PCV, RBC, heterophil to lymphocyte $(\mathrm{H}: \mathrm{L})$ ratio, WBC, weight and SVL and SMI and sexes were determined using t-tests. A Pearson correlation was calculated to look at the association between body temperature (skin and cloacal), weight and SVL with all the hematologic and biochemistry values. To estimate body condition, the Scaled Mass Index (SMI) was used. This index proved to be a better indicator of the relative size of energy reserves and other body components, SMI = Mi [Lo/Li]bSMA (Peig \& Green, 2009). The length (Li) variable has the strongest correlation with mass (Mi) on a log-log scale, since this is likely to be the length that best explains that fraction of mass associated with structural size. The scaling exponent (bSMA) is calculated indirectly by dividing the slope from an ordinary least squares regression and Lo is the mean of the total sample length (Peig \& Green, 2009). All statistical analyses were performed using IBM SPSS ${ }^{2} \mathrm{v} 24$ with a standard $\alpha$ level of 0.05 . In addition, information from nine sample points from 40 Berthold's bush anoles were geocoded and a map was generated using ArcGis 10.1 software (ESRI, Redlands, CA, USA).

\section{Results}


200

201

202

203

204

205

206

207

208

209

210

211

212

213

214

215

216

217

218

219

220

221

222

223

224

225

226

227

228

229

230

231

232

233

234

235

236

237

238

239

\section{Physical examinations}

All lizards appeared to be active and healthy. Female weight ranged from $27 \mathrm{~g}$ to $80 \mathrm{~g}$ (mean \pm $\mathrm{SD}=52.25 \pm 13.56)$ and males weighed from $17 \mathrm{~g}$ to $52 \mathrm{~g}$ (mean $\pm \mathrm{SD}=37.30 \pm 8.86$ ). No evidence of lesions was detected during physical exams. No ectoparasites (acari, ticks, or other macroscopic arthropods) were observed and none of the females had palpable oviductal eggs.

The general body condition of all individuals was between 2.5 to 3.0 and a body mass index was also obtained. The SMI was $3.75( \pm 0.15)$ CI [3.70-3.79]. No significant differences were found between sexes $(t=0.99, p=0.33)$.

\section{Physiological parameters}

No significant differences between sexes in any of the hematological or biochemical parameters were found. Hematological values are presented in Table 1. The morphology of lymphocytes (Fig. 2a), heterophils (Fig. 2b), eosinophils (Fig. 2c), basophils and monocytes (Fig. 2d) were similar to other iguanian species.

Heterophil to lymphocyte (H:L) ratios were calculated (Table 1). Both shape and appearance of erythrocytes and thrombocytes were similar to those reported for other reptiles. Erythrocytes were ellipsoid with central positioned oval nucleus that contain dense purple chromatin with rather irregular margins. The cytoplasm stained orange o pale pink with DiffQuick. Thrombocytes are elliptical with the nucleus located in a central position, containing dense chromatin that stained purple. The cytoplasm is colorless. Polychromatophilic erythrocyte percentage was $1.33( \pm 0.69)$ (Table 1$)$. Intraerythrocytic parasites were found in nine (three females and six males) of the 40 individuals (22.5\% of the total sample) (Fig. 2e). No significant differences were found between individuals with and without hemoparasites for the following variables: $\operatorname{PCV}(\mathrm{t}=-1.24, \mathrm{p}=0.22), \mathrm{RBC},(\mathrm{t}=1.11, \mathrm{p}=0.27), \mathrm{WBC}(\mathrm{t}=0.64, \mathrm{p}=0.52), \mathrm{H}: \mathrm{L}$ ratio $(\mathrm{t}=1.55, \mathrm{p}=0.28)$, weight $(\mathrm{t}=-0.16, \mathrm{p}=0.86)$, SVL $(\mathrm{t}=-1.43, \mathrm{p}=0.16)$, and polychromasia $(\mathrm{t}=-0.64 \mathrm{p}=0.53)$.

Clinical biochemistry values are reported in Table 2. A wide range was observed in AST (15.1 U/L - 139.40 U/L) and CK (122.9 U/L - 6848.20 U/L), and both muscle enzymes were highly correlated $(\mathrm{r}=0.795, \mathrm{p}<0.001)$. Skin temperature varied between $18.8^{\circ} \mathrm{C}$ and $26.2^{\circ} \mathrm{C}$ (mean $\pm \mathrm{SD}=22.31 \pm 1.74)$ and cloacal temperature varied between $21.2^{\circ} \mathrm{C}$ and $32.4^{\circ} \mathrm{C}(\mathrm{mean} \pm$ $\mathrm{SD}=25.22 \pm 2.11)$. A negative correlation was found between skin temperature $(\mathrm{r}=-0.51, \mathrm{p}=$ $0.001)$ and cloacal temperature $(r=-0.42, p=0.007)$ with AST (Fig. 3a). The same occurred between skin temperature $(r=-0.51, p=0.001)$ and cloacal temperature $(r=-0.42, p=0.007)$ with CK (Fig. 3b). A positive correlation was found in females, but not in males, between calcium $(r=0.57, p=0.009)$, total protein $(r=0.49, p=0.03)$ and the calcium/phosphorus $(\mathrm{Ca} / \mathrm{P})$ ratio $(\mathrm{r}=0.71, \mathrm{p}<0.001)$ with weight. 


\section{Phylogenetic comparison}

241 Even though hematological and biochemical information is not available for a number of

242 iguanian families (e.g., Leiocephalidae, Crotaphytidae, Hoplocercidae, Opluridae and

243 Leiosauridae), some comparisons are still possible. For hematological parameters, WBC was

244 found to be higher for Polychrotidae, Liolaemidae and Corytophanidae (all three

245 phylogenetically related) compared to other families, while the number of lymphocytes is high in

246 Polychrotidae and comparable with Iguanidae and Tropiduridae (Figure 4). For biochemical

247 parameters, Polychrotidae showed a higher value of total protein when compared to

248 Tropiduridae, although no other value differed significantly (Figure 5).

249

250

251

252

253

254

255

256

257

258

259

260

261

262

263

264

265

266

267

268

269

270

271

272

273

274

275

276

277

278

279

\section{Discussion}

Health assessments provide baseline information that can be used to understand future changes in the health status of wildlife populations. Both physical examination and internal physiological data (i.e. body temperature, hematology and biochemistry) can serve as valuable tools for evaluating and monitoring the health of wild populations (Stacy, Alleman \& Sayler, 2011; Campbell, 2014), especially when such assessments provide the only available data for a given species (Innis, 2014). Although physical examinations are common in many taxa, including reptiles, there are no known reports assessing hematology and biochemistry parameters in freeranging, canopy dwelling lizards. Therefore, this study is important to report such data for Polychrus gutturosus.

Physical examination of Berthold's bush anoles showed no evident abnormalities, suggesting that all animals were apparently healthy. Body condition is assumed to influence an animal's health and fitness (Peig \& Green, 2009) and although the body condition index cannot be compared with other studies, the fact that no differences were found between sexes indicates an evenness to our sample. These findings may indicate that environmental conditions such as availability of habitat, food and water are fulfilling the requirements of the individuals of the population studied, despite being located in an altered area (Fig. 1). Furthermore, healthy animals also suggest that physiological parameters, such as hematological and biochemical blood values, may be within a normal range. Blood cell counts and cell morphology, however, are highly variable between reptilian species, even among members of the same genus (Stacy, Alleman \& Sayler, 2011; Innis, 2014). Such variation is caused by both intrinsic and extrinsic factors like age, sex, season, presence of environmental stressors, parasite load, nutritional status, and capture and restraint (Campbell, 2014; Heatley \& Russell, 2019). For that reason, the results in this study are compared with other related lizard species.

PCV and RBC counts were similar to closely related lizards (James et al., 2006; Dallwig et al., 2011; McEntire et al., 2018), and polychromatophilic cell mean was $1.33 \%$. In normal reptiles, the percentage of polychromatophilic red cells is from $>1$ to $2.5 \%$ (Heatley \& Russell, 2019). Erythrocyte counts and the presence of a high percentage of polychromasia have been used as an important parameter for health assessments of wild lizards. For example, Smyth et al. (2014) found that sleepy lizards (Tiliqua rugosa) in agricultural environments had a regenerative 
280

281

282

283

284

285

286

287

288

289

290

291

292

293

294

295

296

297

298

299

300

301

302

303

304

305

306

307

308

309

310

311

312

313

314

315

316

317

318

319

anemia (low PCV and increased polychromatophils) compared to animals in non-agricultural areas.

In squamate species, lymphocytes are the predominating circulating cell, usually $80 \%$ of the leukogram (Sykes \& Klaphake, 2015; Heatley \& Russell, 2019), although in some species heterophils can be the main circulating leukocyte. Hematological data comparisons with other closely related families showed that lymphocytes were the main white cell population in $P$. gutturosus, followed by heterophils and monocytes (Fig. 5). For example, Polychrus, Amblyrhynchus, Microlophus, Intellagama and Furcifer include species that are predominantly lymphocytic, while heterophils are the predominant circulating leukocyte cell in Basiliscus, Cyclura, Phrynosoma and Liolaemus (Fig. 5). These blood circulating cells are important in calculating the heterophil to lymphocyte ratio (H:L ratio) which has been used as an indicator of stress in reptiles (Aguirre, et al., 1995; Cartledge, Gartrell \& Jones, 2005; Davis, Maney \& Maerz, 2008; French, Fokidis \& Moore, 2008; Silvestre, 2014) and wild and domestic birds (Vleck, et al., 2000; Huff et al., 2005).

Normal H:L ratio in reptile species with more lymphocytes circulating than heterophils will have potentially delayed responses to heterophilia (Davis, Maney \& Maerz, 2008; Campbell, 2014; Silvestre, 2014). It has also been demonstrated that in other vertebrates with low H:L ratio (which means that lymphocytes are the predominant cell), H:L increase rapidly after stress events (Cïrule et al., 2012). Although we are aware of H:L limitations in reptiles, we consider that this measurement is important for animal health assessments.

Most biochemistry analytes measured in Polychrus gutturosus were within similar ranges of other iguanian species. CK and AST values were similar to those found in Cyclura species (Alberts et al., 1998; James et al., 2006; Maria et al., 2007) and Basiliscus plumifrons (Dallwig et al., 2011), in which the length of the capture, holding period, restraint and venipuncture results in elevated CK and AST levels. In reptiles, CK is an enzyme considered to be specific to muscle cells and thus with muscle damage will elevate in the blood, while AST is a less specific enzyme and is primarily in liver but also in muscle tissue (Anderson et al., 2013; Bogan \& Mitchel, 2014; Petrosky, Knoll \& Innis, 2015). A high positive correlation between AST and CK was found in P. gutturosus, suggesting that higher levels of the enzyme AST may be associated with muscle tissue along with $\mathrm{CK}$ in this lizard species.

A negative correlation was found between AST and CK and both skin and cloacal temperatures (Fig. 4). As ectotherms, reptiles experience temperature-induced changes in metabolic rate (Niewiarowski \& Waldschmidt, 1992). When reptiles are resting and their body temperature is low, their metabolic rate and energy stay at basal levels (Vitt \& Caldwell, 2014); however, movement or using anaerobic metabolism in specific situations require more energy than the basal rate, so reptiles attain higher body temperatures (Randall et al., 2002). During high-intensity, short-duration activity (e.g., capture and sampling of the lizards [see Materials and Methods]), the concentration of ATP within muscles can be maintained constant by continuous re-phosphorylation of ADP by the CK reaction (Randall et al., 2002). As a result, an animal can use the large reserve of high-energy phosphate in CK to power muscle contraction 
320

321

322

323

324

325

326

327

328

329

330

331

332

333

334

335

336

337

338

339

340

341

342

343

344

345

346

347

348

349

350

351

352

353

354

355

356

357

358

359

until oxidative and anaerobic metabolism start to generate ATP, allowing it to move for much longer (Randall et al., 2002). Since our sampling (capture, restrain and venipuncture) was performed at night, individuals of $P$. gutturosus had lower body temperatures and thus likely lower oxygen consumption (Clark, Butler \& Frappell, 2006), such that muscle contraction rapidly started using anaerobic (glycolytic) pathway to keep its activity (Bennett, 1980). Anaerobic muscular metabolism also generates an electrolyte imbalance (mainly calcium) and releases oxygen and lactate, leading to muscle injury (Giannoglou, Chatzizisis \& Misirli, 2007). Such muscle damage causes CK and AST enzymes to leak into the blood stream from muscle cells (Allison, 2005). Hence, increased plasma activities of both CK and AST suggest active or recent muscle injury (Silvestre, 2014). Therefore, animals at lower temperatures, with lower oxygen consumption, utilized the anaerobic pathway at the moment of capture, leading to more muscle damage, resulting in the release of more CK and AST than lizards captured at higher temperatures, which probably utilized anaerobic muscular activity later.

No differences between sexes were found among hematological and biochemical variables. In other iguanian lizards where males are larger than females, significative differences in biochemical values have been found between sexes (Dallwig et al., 2011). For example, males of the San Cristóbal lava lizard (Microlophus bivittatus) had higher hemoglobin, PCV and glucose than females (Arguedas et al., 2018), and female green iguanas (Iguana iguana) had higher hemoglobin and PCV than males (Harr et al., 2001). Interestingly, in Phrynosoma cornutum, where females are larger than males, basophil counts were lower in females than in males (McEntire et al., 2018). Most explanations for differences between sexes in hematological and biochemical values are based on reproductive physiological status or hormonal biases (McEntire et al., 2018), although the reasons why P. gutturosus have no difference between sexes are unknown.

A positive correlation between calcium and proteins with body weight was found for females but not for males. It is known that during vitellogenesis, circulating estrogens raise calcium, phosphorus and proteins in plasma (Bonnet, Naulleau \& Mauget, 1994; Jones, 2011), however, no correlation between $\mathrm{P}$ and weight was found. Calcium increases during vitellogenesis and folliculogenesis for most squamates, the investment of calcium in eggshells is considerably less than for yolk (Stuart \& Ecay, 2010). We hypothesize that heavier females may be under active vitellogenesis, increasing their weight due to follicular development.

A correlation was found between calcium to phosphorus $(\mathrm{Ca} / \mathrm{P})$ ratio and weight in females but not in males. $\mathrm{Ca}$ and $\mathrm{P}$ homeostasis are directly interrelated because serum $\mathrm{Ca}$ interplays with serum $\mathrm{P}$ through the modulation of several hormones, such that serum concentration is approximately inversely related (a high $\mathrm{Ca} / \mathrm{P}$ ratio means higher $\mathrm{Ca}$ than $\mathrm{P}$ ) (Madeo et al., 2018). Calcium increases proportionally greater than $P$, resulting in a higher value of $\mathrm{Ca} / \mathrm{P}$. Although the reason for that is unknown, a possible explanation is that parathyroid activity may be higher in heavier females due to larger follicular development. Unfortunately, no literature is available regarding the breeding season on this species, so the reproductive stage of the animals sampled is unknown. 
360

361

362

363

364

365

366

367

368

369

370

371

372

373

374

375

376

377

378

379

380

381

382

383

384

385

386

387

388

389

390

391

392

393

394

395

396

397

398

399

Finally, intraerythrocytic parasites were found in nine individuals, but no differences were found between infected and non-infected animals with hematological values or physical measurements. The presence of hemoparasites in wild reptiles is common (Telford, 2009) and usually considered non-pathogenic (Stacy, Alleman \& Sayler, 2011). Hemoparasite life cycles involve sexual reproduction in an invertebrate host (e.g. ticks, mites, mosquitoes and flies) and asexual reproduction in the reptilian host (Telford, 2009; Campbell, 2015). Since no mites or ticks were found in the lizards sampled (which may be due to their arboreal habits), it is possible that the hemoparasites were transmitted by mosquitoes or flies. Pathogenesis caused by hemoparasite infections in reptiles is unclear, with studies reporting from apparently nondetrimental infections in natural hosts to severe and life-threatening illness in unnatural hosts (Maia et al., 2014). Hence, more research is needed to identify the species of hemoparasite identified here and continued monitoring of these lizard populations to establish actual prevalence of the disease.

Health assessments allow for evaluation of body condition, disease, stress levels, hydration status and temperature changes of wild populations to be detected (Stacy, Alleman \& Sayler, 2011; Innis, 2014) and thus, determine whether a population faces any stress related to environmental changes or anthropogenic causes. In this study, the first baseline data of hematology and clinical biochemistry values for the Berthold's bush anole (Polychrus gutturosus) is reported. Poorly studied species with populations occurring in altered or nonprotected environments can be at greater risk from human activity. Since $P$. gutturosus depends on its arboreal habits, deforestation due to urban or agricultural activities can affect their survival, reduce its habitat and increase the transmission of diseases. Preventing species from becoming threatened requires conservation actions based on scientific knowledge. This includes health assessments of wild populations that can be used for future management and protective actions.

\section{Conclusions}

Hematological and biochemical values were obtained for the first time in this poorly studied arboreal lizard species. The morphology of leukocytes were similar to other iguanians. A positive correlation was found between Aspartate amino transferase (AST) and Creatinine kinase (CK) and a negative correlation between skin and cloacal temperatures with AST and CK. There were positive correlations between female weight and total protein, Calcium, and the Calcium and Phosphorus ratio. No significant inter-sex differences were found, despite females being larger than males. These findings provide baseline data that may be useful if this species faces changes in health status due to anthropogenic causes or natural disturbances in the future.

\section{Acknowledgements}


400 We thank Esteban Castro from VetLab for his help on processing the samples and Mario Baldi 401 from the National University of Costa Rica School of Veterinary Medicine, for elaborating the 402 map. Also, we extend our gratitude to Aaron Solís, Edwin Soto and José Gabriel Barquero for 403 helping in the field. Lastly, we are thankful to Belinda Dick for English editing.

404

405

406

407

408

409

410

411

412

413

414

415

416

417

418

419

420

421

422

423

424

425

426

427

428

429

430

431

432

433

434

435

436

437

438

439

\section{References}

Acosta Chaves V, Ballestero E, Batista A, Chaves G, Ibáñez R, Ines Hladki A, Jaramillo C, Lamar W, Ramírez Pinilla M, Renjifo J, Solórzano A, Urbina N. 2017. Polychrus gutturosus. The IUCN red list of threatened species. Version 2017. Available at https://dx.doi.org/10.2305/IUCN.UK.2017-2.RLTS.T203161A2761248.en (accessed 20 July 2020).

Aguirre AA, Balazs GH, Spraker TR, Gross TS. 1995. Adrenal and hematological responses to stress in juvenile green turtles (Chelonia mydas) with and without fibropapillomas. Physiological Zoology 68:831-854.

Alberts AC, Oliva ML, Worley MB, Telford Jr SR, Morris PJ, Janssen DL (1998) The need for pre-release health screening in animal translocations: a case study of the Cuban iguana (Cyclura nubila). Animal Conservation 1:165-172.

Allison RW. 2005. Laboratory detection of muscle injury. In: Thrall MA, Weiser G, Allison RW, Campbell TW, eds. Veterinary hematology and clinical chemistry. 2nd ed. Iowa: WileyBlackwell, 476-479.

Altizer S, Ostfeld RS, Johnson PT, Kutz S, Harvell CD. 2013. Climate change and infectious diseases: from evidence to a predictive framework. Science 341:514-519.

Anderson ET, Socha VL, Gardner J, Byrd L, Manire CA. 2013. Tissue enzyme activities in the loggerhead sea turtle (Caretta caretta). Journal of Zoo and Wildlife Medicine 44:62-69.

Arguedas R, Steinberg D, Lewbart GA, Deresienski D, Lohmann KJ, Muñoz-Pérez JP, Valle CA. 2018. Haematology and biochemistry of the San Cristóbal Lava Lizard (Microlophus bivittatus). Conservation Physiology 6:coy046. doi:10.1093/conphys/coy046.

Bell KE, Donnelly MA. 2006. Influence of forest fragmentation on community structure of frogs and lizards in northeastern Costa Rica. Conservation Biology 20:1750-1760.

Bennett AF. 1980. The metabolic foundations of vertebrate behavior. BioScience 30:452-456.

Bernal-Valle S, Jiménez-Soto M, Meneses-Guevara A. 2020. Hematology and serum biochemistry values of healthy free-ranging Panamanian White-faced capuchins (Cebus imitator) in Costa Rica. Journal of Wildlife Diseases 56:229-233.

Bogan Jr JE, Mitchell MA. 2014. Characterizing tissue enzyme activities in the American alligator (Alligator mississippiensis). Journal of Herpetological Medicine and Surgery 24:77-81.

Bonnet X, Naulleau G, Mauget R. 1994. The influence of body condition on 17- $\beta$ estradiol levels in relation to vitellogenesis in female Vipera aspis (Reptilia, Viperidae). General and Comparative Endocrinology 93:424-437. 
440 Bringsøe H, Alfaro Sánchez O, Hansen HO. 2016. First record and distributional extension for

441

442

443

444

445

446

447

448

449

450

451

452

453

454

455

456

457

458

459

460

461

462

463

464

465

466

467

468

469

470

471

472

473

474

475

476

477

478

Polychrus gutturosus Berthold, 1845 (Squamata: Polychrotidae) in the Península de Nicoya of northwestern Costa Rica, with a new record from Provincia de San José. Mesoamerican Herpetology 3:1091-1094.

Brusch GA, Taylor EN, Whitfield SM. 2016. Turn up the heat: thermal tolerances of lizards at La Selva, Costa Rica. Oecologia 180:325-334.

Campbell TW. 2014. Clinical pathology. In: Mader DR, Divers SJ, eds. Current therapy in reptile medicine and surgery. Missouri: Saunders, 70-92.

Campbell TW. 2015. Exotic animal hematology and cytology. 4th ed. Oxford: Iowa State University Press, John Wiley \& Sons.

Cartledge VA, Gartrell B, Jones SM. 2005. Adrenal and white cell count responses to chronic stress in gestating and postpartum females of the viviparous skink Egernia whitii (Scincidae). Comparative Biochemistry and Physiology Part A: Molecular \& Integrative Physiology 141:100-107.

Cascante-Marín A. 2012. Ubicación, relieve y clima de la zona de El Rodeo. Brenesia 77:15-22.

Cīrule D, Krama T, Vrublevska J, Rantala MJ, Krams I. 2012. A rapid effect of handling on counts of white blood cells in a wintering passerine bird: a more practical measure of stress? Journal of Ornithology 153:161-166.

Clark TD, Butler PJ, Frappell PB. 2006. Factors influencing the prediction of metabolic rate in a reptile. Functional Ecology 20:105-113.

Dallwig RK, Paul-Murphy J, Thomas C, Medlin S, Vaughan C, Sullivan L, Sladky KK, Ramirez O, Herrera G. 2011. Hematology and clinical chemistry values of free-ranging basilisk lizards (Basiliscus plumifrons) in Costa Rica. Journal of Zoo and Wildlife Medicine 42:205-213.

Davis AK, Maney DL, Maerz JC. 2008. The use of leukocyte profiles to measure stress in vertebrates: a review for ecologists. Functional Ecology 22:760-772.

Divers SJ. 2019. Medical history and physical examination. In: Divers SJ, Stahl SJ, eds. Mader's reptile and amphibian medicine and surgery. 3rd ed. Missouri: Elsevier Health Sciences, 385-404.

Ellman MM. 1997. Hematology and plasma chemistry of the inland bearded dragon, Pogona vitticeps. Bulletin of the Association of Reptilian and Amphibian Veterinarians 7:10-12.

Espinosa-Avilés D, Salomón-Soto VM, Morales-Martínez S. 2008. Hematology, blood chemistry, and bacteriology of the free-ranging Mexican beaded lizard (Heloderma horridum). Journal of Zoo and Wildlife Medicine 39:21-27.

French SS, Fokidis HB, Moore MC. 2008. Variation in stress and innate immunity in the tree lizard (Urosaurus ornatus) across an urban-rural gradient. Journal of Comparative Physiology B 178:997-1005.

Giannoglou GD, Chatzizisis YS, Misirli G. 2007. The syndrome of rhabdomyolysis: pathophysiology and diagnosis. European Journal of Internal Medicine 18:90-100.

Peer] reviewing PDF | (2020:10:53394:1:1:NEW 3 Dec 2020) 
479

480

481

482

483

484

485

486

487

488

489

490

491

492

493

494

495

496

497

498

499

500

501

502

503

504

505

506

507

508

509

510

511

512

513

514

515

516

517

Gómez-Hoyos DA, Escobar-Lasso S, Suarez-Joaqui T, Velasco JA. 2015. Predation on the bush anole Polychrus gutturosus by the parrot snake Leptophis ahaetulla, with a new record of the bush anole for the Gorgona Island National Natural Park, Colombia. Herpetology Notes 8:297-301.

Hagnauer Barrantes I. 2012. Determinación de valores referenciales de hematología y química plasmática en una población de perezosos de las especies Choloepus hoffmanni y Bradypus variegatus de vida libre en la zona de San José de Upala, Alajuela. D. Magister. Thesis, Universidad Nacional de Costa Rica.

Harr KE, Alleman AR, Dennis PM, Maxwell LK, Lock BA, Bennett RA, Jacobson ER. 2001. Morphologic and cytochemical characteristics of blood cells and hematologic and plasma biochemical reference ranges in green iguanas. Journal of the American Veterinary Medical Association 218:915-921.

Heatley JJ, Russel KE. 2019. Hematology. In: Divers SJ, Stahl SJ, eds. Mader's reptile and amphibian medicine and surgery. 3rd ed. Missouri: Elsevier Health Sciences, 301-318.

Henen BT, Hofmeyr MD, Baard EHW. 2013. Body of evidence: forensic use of baseline health assessments to convict wildlife poachers. Wildlife Research 40:261-268.

Huff GR, Huff WE, Balog JM, Rath NC, Anthony NB, Nestor KE. 2005. Stress response differences and disease susceptibility reflected by heterophil to lymphocyte ratio in turkeys selected for increased body weight. Poultry science. 84:709-17.

Innis CJ. 2014. Conservation issues. In: Mader DR, Divers SJ, eds. Current therapy in reptile medicine and surgery. Missouri: Saunders, 296-303.

James SB, Iverson J, Greco V, Raphael BL. 2006. Health assessment of Allen Cays rock iguana, Cyclura cychlura inornata. Journal of Herpetological Medicine and Surgery 16:93-98.

Jones SM. 2011. Hormonal regulation of ovarian function in reptiles. In: Norris DO, Lopez KH, eds. Hormones and reproduction of vertebrates. Volume 3: Reptiles. London: Academic Press, 89-115.

Koch C, Venegas PJ, Garcia-Bravo A, Böhme W. 2011. A new bush anole (Iguanidae, Polychrotinae, Polychrus) from the upper Marañon basin, Peru, with a redescription of Polychrus peruvianus (Noble, 1924) and additional information on P. gutturosus Berthold, 1845. ZooKeys 141:79-107.

Laube A, Pendl H, Clauss M, Altherr B, Hatt JM. 2016. Plasma biochemistry and hematology reference values of captive panther chameleons (Furcifer pardalis) with special emphasis on seasonality and gender differences. Journal of Zoo and Wildlife Medicine 47:743-753.

Leenders T. 2019. Reptiles of Costa Rica: A field guide. New York: Cornell University Press, 246-247.

Lewbart GA, Hirschfeld M, Brothers JR, Muñoz-Pérez JP, Denkinger J, Vinueza L, Garcia J, Lohmann KJ. 2015. Blood gases, biochemistry and haematology of Galápagos marine iguanas (Amblyrhynchus cristatus). Conservation Physiology 3:cov034. doi:10.1093/conphys/cov034.

Peer) reviewing PDF | (2020:10:53394:1:1:NEW 3 Dec 2020) 
518 Maceda-Veiga A, Figuerola J, Martínez-Silvestre A, Viscor G, Ferrari N, Pacheco M. 2015. 519 Inside the Redbox: applications of haematology in wildlife monitoring and ecosystem 520 health assessment. Science of the Total Environment 514:322-332.

521 Madeo B, Kara E, Cioni K, Vezzani S, Trenti T, Santi D, Simoni M, Rochira V. 2018. Serum

522 calcium to phosphorous $(\mathrm{Ca} / \mathrm{P})$ ratio is a simple, inexpensive, and accurate tool in the 523 diagnosis of primary hyperparathyroidism. JBMR Plus 2:109-117.

524

525

526

527

528

529

530

531

532

533

534

535

536

537

538

539

540

541

542

543

544

545

546

547

548

549

550

551

552

553

554

555

556

Madliger CL, Franklin CE, Hultine KR, van Kleunen M, Lennox RJ, Love OP, Rummer JL, Cooke SJ. 2017. Conservation physiology and the quest for a 'good' Anthropocene. Conservation Physiology 5:cox003. doi:10.1093/conphys/cox003.

Maia JP, Harris DJ, Carranza S, Gómez-Díaz E. 2014. A comparison of multiple methods for estimating parasitemia of hemogregarine hemoparasites (Apicomplexa: Adeleorina) and its application for studying infection in natural populations. PLoS One 9:e95010. doi:10.1371/journal.pone.0095010.

Maria R, Ramer J, Reichard T, Tolson PJ, Christopher MM. 2007. Biochemical reference intervals and intestinal microflora of free-ranging Ricord's iguanas (Cyclura ricordii). Journal of Zoo and Wildlife Medicine 38:414-419.

Mathews F, Moro D, Strachan R, Gelling M, Buller N. 2006. Health surveillance in wildlife reintroductions. Biological Conservation 131:338-347.

Mayer J, Knoll J, Innis C, Mitchell MA. 2005. Characterizing the hematologic and plasma chemistry profiles of captive Chinese water dragons, Physignathus cocincinus. Journal of Herpetological Medicine and Surgery 15:45-52.

McEntire MS, Pich A, Zordan M, Barber D, Rains N, Erxleben D, Heatley JJ, Sanchez CR. 2018. Hematology of free-ranging and managed Texas horned lizards (Phrynosoma cornutum). Journal of Wildlife Diseases 54:802-808.

Niewiarowski PH, Waldschmidt SR. 1992. Variation in metabolic rates of a lizard: use of SMR in ecological contexts. Functional Ecology 6:15-22.

Peig J, Green AJ. 2009. New perspectives for estimating body condition from mass/length data: the scaled mass index as an alternative method. Oikos 118:1883-1891.

Petrosky KY, Knoll JS, Innis C. 2015. Tissue enzyme activities in Kemp's Ridley turtles (Lepidochelys kempii). Journal of Zoo and Wildlife Medicine 46:637-640.

Pyron RA, Burbrink FT, Wiens JJ. 2013. A phylogeny and revised classification of Squamata, including 4161 species of lizards and snakes. BMC Evolutionary Biology 13:93.

Randall DJ, Burggren WW, French K, Eckert R. 2002. Eckert animal physiology: Mechanisms and adaptations. 4th ed. New York: W.H. Freeman and Co.

Roberts WE. 1997. Behavioral observations of Polychrus gutturosus, a sister taxon of Anoles. Herpetological Review 28:184-185.

Ruiz JE, Gutiérrez A, Flóres Rocha O. 2016. Nuevo registro de la iguanita de bosque, Polychrus gutturosus Berthold, 1846 para la región de Santo Domingo (Chontales) Nicaragua. Cuadernos de Herpetología 30:39-40. 
557

558

559

560

561

562

563

564

565

566

567

568

569

570

571

572

573

574

575

576

577

578

579

580

581

582

583

584

585

586

587

588

589

590

591

Savage JM. 2002. The amphibians and reptiles of Costa Rica: A herpetofauna between two continents, between two seas. Chicago: University of Chicago Press.

Schinnerl M, Aydinonat D, Schwarzenberger F, Voigt CC. 2011. Hematological survey of common neotropical bat species from Costa Rica. Journal of Zoo and Wildlife Medicine 42:382-391.

Silvestre AM. 2014. How to assess stress in reptiles. Journal of Exotic Pet Medicine 23:240-243. Sinervo B, Méndez-de-la-Cruz F, Miles DB, Heulin B, Bastiaans E, Villagrán-Santa Cruz M, Lara-Resendiz R, Martínez-Méndez N, Calderón-Espinosa ML, Meza-Lázaro RN, Gadsen H. 2010. Erosion of lizard diversity by climate change and altered thermal niches. Science 328:894-899.

Smyth AK, Smee E, Godfrey SS, Crowther M, Phalen D. 2014. The use of body condition and haematology to detect widespread threatening processes in sleepy lizards (Tiliqua rugosa) in two agricultural environments. Royal Society Open Science 1:140257. doi:10.1098/rsos.140257.

Stacy NI, Alleman AR, Sayler KA. 2011. Diagnostic hematology of reptiles. Clinics in Laboratory Medicine 31:87-108.

Stewart JR, Ecay TW. 2010. Patterns of maternal provision and embryonic mobilization of calcium in oviparous and viviparous squamate reptiles. Herpetological Conservation and Biology. 5:341-59.

Sykes JM, Klaphake, E. 2015. Reptile hematology. Clinics in Laboratory Medicine 35:661-680.

Taylor EH. 1956. A review of the lizards of Costa Rica. Kansas University Science Bulletin 38:3-322.

Telford Jr SR. 2009. Hemoparasites of the reptilia: Color atlas and text. New York: CRC Press, 376.

Valle CA, Ulloa C, Deresienski D, Regalado C, Muñoz-Pérez JP, Garcia J, Hardesty BD, Skehel A, Lewbart GA. 2018. Health status of great frigatebirds (Fregata minor) determined by haematology, biochemistry, blood gases, and physical examination. Conservation Physiology 6:coy034. doi:10.1093/conphys/coy034.

Vitt LJ, Caldwell JP. 2014. Herpetology: An introductory biology of amphibians and reptiles. 4th ed. London: Academic Press.

Vleck CM, Vertalino N, Vleck D, Bucher TL. 2000. Stress, corticosterone, and heterophil to lymphocyte ratios in free-living Adélie penguins. The condor. 102:392-400.

Whitfield SM, Bell KE, Philippi T, Sasa M, Bolaños F, Chaves G, Savage JM, Donnelly MA. 2007. Amphibian and reptile declines over 35 years at La Selva, Costa Rica. Proceedings of the National Academy of Sciences of the United States of America 104:8352-8356. 


\section{Figure 1}

Map of Costa Rica showing the location of the Berthold's bush anole (Polychrus gutturosus) sampling site with exact coordinate points along an approximately $3 \mathrm{~km}$ trail showing where they were captured. The yellow marks refer to collection points, no Map of Costa Rica showing the location of the Berthold's bush anole (Polychrus gutturosus) sampling site with exact coordinate points along an approximately $3 \mathrm{~km}$ trail showing where they were captured. The yellow marks refer to collection points, not to individuals.

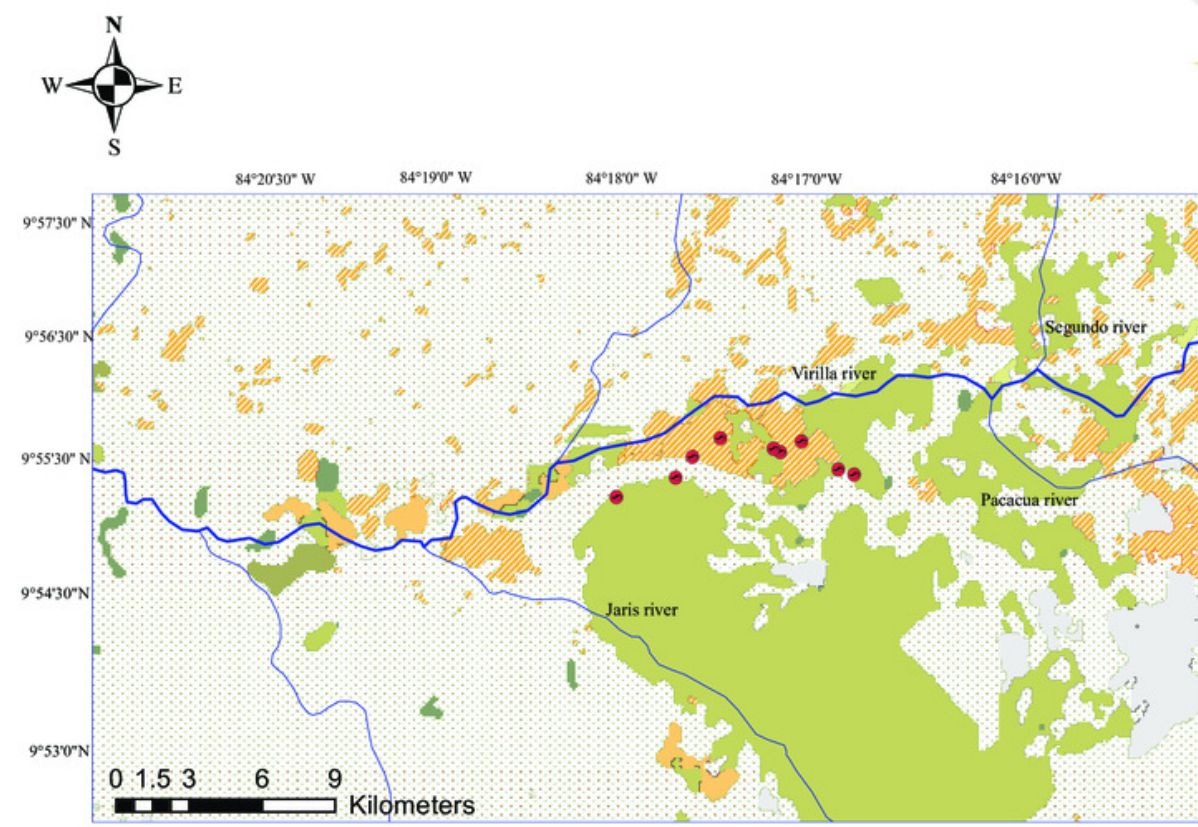

(-) Sampled points (Polychrus gutturosus)-Costa Rica

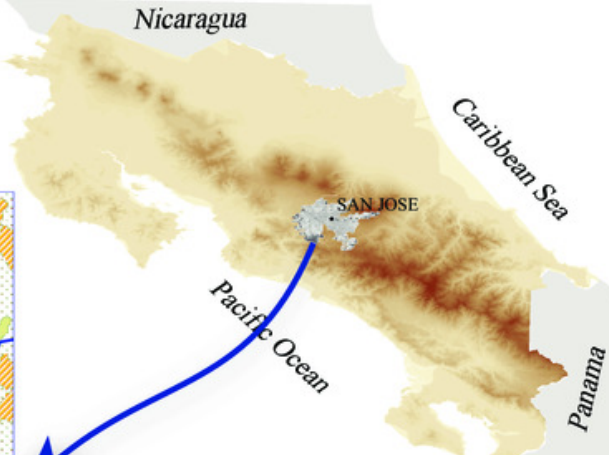

Land Use

SECONDARY FOREST DEFORESTED AREAS COFFEE PLANTATION NATURAL FOREST AGRICULTURAL AREA FOREST PLANTATION URBAN AREAS 


\section{Figure 2}

Figure 2

Figure 2. Photographs of selected Berthold's bush anole (Polychrus gutturosus) blood cells stained with Diff-Quick stain at 100x. (a) heterophil (b) basophil (c) lymphocyte (d) monocyte (e) intraerythrocytic hemoparasite.

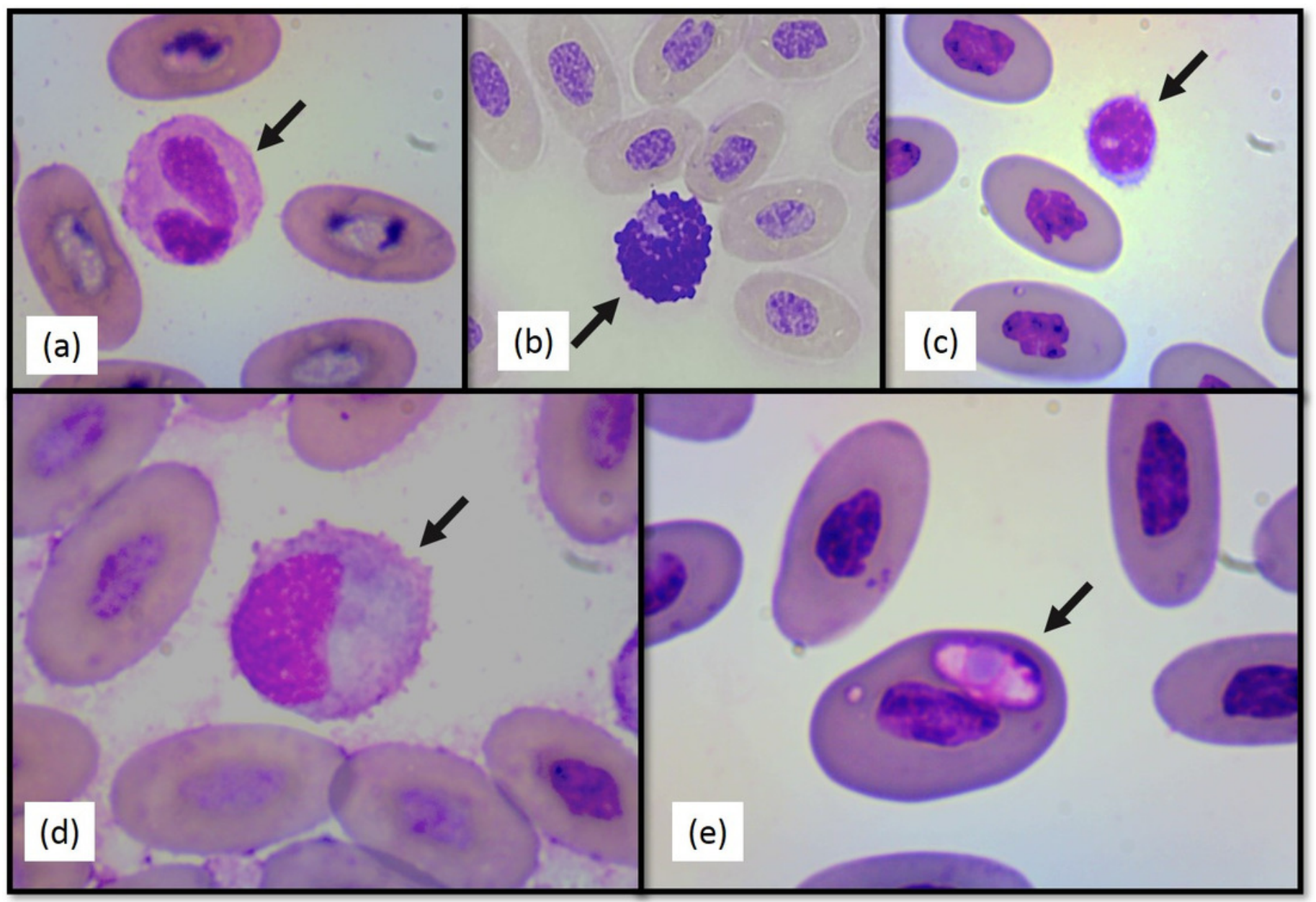


Figure 3

Fig 3

Linear correlations of skin and cloacal temperatures $\left({ }^{\circ} \mathrm{C}\right)$ of the Berthold's bush anole (Polychrus gutturosus) with blood values of (a) aspartate amino transferase (AST) and (b) creatinine kinase (CK). 

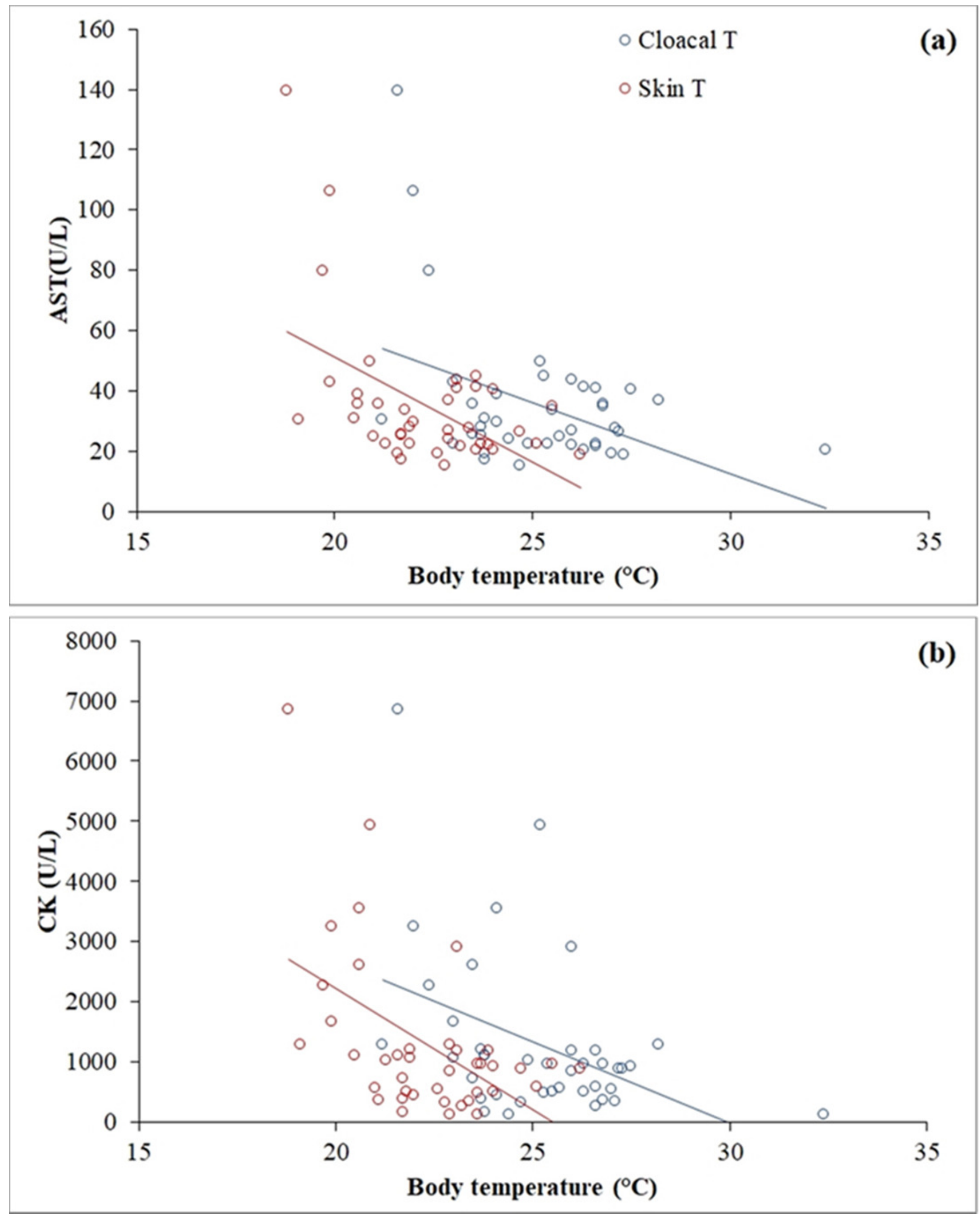


\section{Figure 4}

Figure 4

Mean \pm SD (or range) of hematological parameters extracted from the literature for species of the infraorder Iguania, as a comparison with the Berthold's bush anole (Polychrus gutturosus). Also depicted are the phylogenetic relationships (adapted from Pyron et al. [2013]) of iguanian families for which hematological information was available. The full name of each species is: Furcifer pardalis (panther chameleon) Laube et al. 2016; Intellagama lesueurii (Australian water dragon) Johnson et al. 2018; Microlophus bivittatus (San Cristóbal lava lizard) Arguedas et al. 2018; Amblyrhynchus cristatus (marine iguana) Lewbart et al. 2015; Cyclura cychlura (Andros Island iguana) James et al. 2006, Phrynosoma cornutum (Texas horned lizard) McEntire et al. 2018; Liolaemus wiegmannii (Wiegmann's lizard) Ceballos de Bruno 1995 and Basiliscus plumifrons (green basilisk) Dallwig et al. 2011. ND = No Data.

\begin{tabular}{|c|c|c|c|c|c|c|c|c|c|}
\hline \multirow[t]{10}{*}{ Iguania } & Family & PCV (\%) & $\begin{array}{c}\text { WBC } \\
\left(10^{9} / \mathrm{L}\right)\end{array}$ & $\begin{array}{c}\text { Heterophils } \\
\left(10^{9} / \mathrm{L}\right)\end{array}$ & $\begin{array}{c}\text { Heterophils } \\
(\%)\end{array}$ & $\begin{array}{c}\text { Lymphocytes } \\
\left(10^{9} / \mathrm{L}\right)\end{array}$ & $\begin{array}{c}\text { Lymphocytes } \\
(\%)\end{array}$ & $\begin{array}{c}\text { Monocytes } \\
\left(10^{9} / \mathrm{L}\right)\end{array}$ & $\begin{array}{c}\text { Monocytes } \\
(\%)\end{array}$ \\
\hline & $\begin{array}{c}\text { Chamaeleonidae } \\
\text { (F.pardalis) }\end{array}$ & $26.30 \pm 6.10$ & $7.30 \pm 3.10$ & ND & $23.90 \pm 6.30$ & ND & $67.30 \pm 7.80$ & ND & $8.80 \pm 4.00$ \\
\hline & $\begin{array}{l}\text { - Agamidae } \\
\quad \text { (I. lesueurii) }\end{array}$ & $\begin{array}{c}30.22 \\
(21.00-43.00)\end{array}$ & $\begin{array}{c}5.90 \\
(0.88-9.90)\end{array}$ & ND & $\begin{array}{c}35.09 \\
(14.00-69.00)\end{array}$ & ND & $\begin{array}{c}51.28 \\
(18.00-76.00)\end{array}$ & ND & $\begin{array}{c}8.06 \\
(2.00-27.00)\end{array}$ \\
\hline & $\begin{array}{l}\text { - Tropiduridae } \\
\text { ( } M \text { bivittatus })\end{array}$ & $33.39 \pm 5.90$ & ND & ND & $5.40 \pm 4.98$ & ND & $86.04 \pm 5.43$ & ND & $7.16 \pm 7.45$ \\
\hline & $\begin{array}{l}\text { Iguanidae } \\
\text { (A. cristatus })\end{array}$ & $27.05 \pm 5.67$ & ND & ND & $10.09 \pm 8.29$ & ND & $83.36 \pm 11.64$ & ND & $6.05 \pm 3.92$ \\
\hline & $\begin{array}{l}\text { Iguanidae } \\
(\text { C. cychlura })\end{array}$ & $29.06 \pm 3.70$ & $6.91 \pm 2.57$ & $4.25 \pm 1.84$ & ND & $1.28 \pm 0.68$ & ND & $0.24 \pm 0.19$ & ND \\
\hline & $\begin{aligned} \text { - Phrynosomatidae } \\
\\
\text { (P. cormutum })\end{aligned}$ & $26.80 \pm 5.44$ & $3.04 \pm 0.94$ & $1.41 \pm 0.58$ & $45.40 \pm 9.00$ & $1.12 \pm 0.37$ & $37.30 \pm 8.60$ & $0.17 \pm 0.11$ & $5.48 \pm 3.07$ \\
\hline & $\begin{array}{l}\text { Polychrotidae } \\
\text { (P. gutturosus ) }\end{array}$ & $31.75 \pm 4.53$ & $19.44 \pm 6.66$ & $2.66 \pm 1.36$ & $13.78 \pm 5.14$ & $14.37 \pm 5.36$ & $74.13 \pm 10.01$ & $1.76 \pm 1.71$ & $8.60 \pm 6.62$ \\
\hline & $\begin{array}{l}\text { Liolaemidae } \\
\text { (L. wiegmanni })\end{array}$ & ND & $\begin{array}{c}19.13 \\
(6.60-45.00)\end{array}$ & ND & $\begin{array}{c}50.00 \\
(23-90)\end{array}$ & ND & $\begin{array}{c}36.00 \\
(10-60)\end{array}$ & ND & $\begin{array}{c}7.00 \\
(4-32)\end{array}$ \\
\hline & $\begin{array}{l}\text { Corytophanidae } \\
\text { (B. plumifrons) }\end{array}$ & $31.40 \pm 8.00$ & $18.70 \pm 8.40$ & $13.20 \pm 5.90$ & ND & $3.60 \pm 2.20$ & ND & $1.40 \pm 1.20$ & ND \\
\hline
\end{tabular}




\section{Figure 5}

Figure 5

Mean \pm SD (or range) of biochemical parameters extracted from the literature for species of the infraorder Iguania, as a comparison with the Berthold's bush anole (Polychrus gutturosus). Also depicted are the phylogenetic relationships (adapted from Pyron et al. [2013]) of iguanian families for which biochemical information was available. The full name of each species is: Furcifer pardalis (panther chameleon), Intellagama lesueurii (Australian water dragon) Johnson et al. 2018; Pogona vitticeps (bearded dragon), Microlophus bivittatus (San Cristóbal lava lizard) Arguedas et al. 2018; Iguana iguana (green iguana) Harr et al. 1998); Cyclura cychlura (Andros Island iguana); James et al. 2006 and Basiliscus plumifrons (green basilisk.) Dallwig et al. 2011. ND = No Data.

\begin{tabular}{|c|c|c|c|c|c|c|c|c|c|c|}
\hline Iguania & Family & $\begin{array}{c}\begin{array}{c}\text { Glucose } \\
(\mathrm{mmol} / \mathrm{L})\end{array}\end{array}$ & $\begin{array}{c}\text { Total Protein } \\
(\mathrm{g} / \mathrm{L})\end{array}$ & $\begin{array}{c}\text { Albumin } \\
(\mathrm{g} / \mathrm{L})\end{array}$ & $\begin{array}{c}\text { Calcium } \\
(\mathrm{mmol} / \mathrm{L})\end{array}$ & $\begin{array}{c}\text { Phosphorus } \\
(\mathrm{mmol} / \mathrm{L})\end{array}$ & $\begin{array}{l}\text { Uric acid } \\
(\mathrm{mmol} / \mathrm{L})\end{array}$ & $\begin{array}{c}\text { Cholesterol } \\
(\mathrm{mmol} / \mathrm{L})\end{array}$ & AST (U/L) & CK (U/L) \\
\hline & $f_{\text {(I. lesueurii })}^{\text {Agamidae }}$ & $\begin{array}{c}8.85 \\
(5.27-12.17)\end{array}$ & $\begin{array}{c}47.38 \\
(28.00-72.00)\end{array}$ & ND & $\begin{array}{c}6.07 \\
(2.52-30.90)\end{array}$ & $\begin{array}{c}1.99 \\
(1.20-4.01)\end{array}$ & $\begin{array}{c}0.21 \\
(0.01-1.05)\end{array}$ & ND & ND & $\begin{array}{c}1703.00 \\
(42-7018)\end{array}$ \\
\hline & $\begin{array}{l}\text { Agamidae } \\
\text { (P. vitticeps) }\end{array}$ & $11.70 \pm 2.20$ & $66.00 \pm 12.00$ & ND & $2.95 \pm 0.95$ & $1.90 \pm 0.61$ & $0.31 \pm 0.15$ & $17.40 \pm 5.92$ & ND & ND \\
\hline & $\begin{aligned} \text { - Tropiduridae } \\
\text { (M bivittatus })\end{aligned}$ & $15.11 \pm 2.55$ & $81.0 \pm 10.60$ & ND & ND & ND & ND & ND & ND & ND \\
\hline & $\begin{array}{l}\text { Iguanidae } \\
(\text { C. cychlura })\end{array}$ & $10.50 \pm 2.18$ & $48.0 \pm 8.80$ & $20.30 \pm 3.80$ & $3.25 \pm 2.30$ & $1.72 \pm 0.74$ & $0.10 \pm 0.12$ & $2.51 \pm 0.87$ & $29.47 \pm 16.38$ & $\begin{array}{c}2342.00 \pm \\
2572.79\end{array}$ \\
\hline & $\begin{aligned} \text { - Polychrotidae } & \text { (P. gutturossus) }\end{aligned}$ & $11.96 \pm 2.04$ & $75.10 \pm 7.80$ & $17.91 \pm 6.34$ & $3.81 \pm 1.64$ & $2.46 \pm 0.85$ & $0.22 \pm 0.21$ & $8.97 \pm 3.16$ & $35.08 \pm 23.86$ & $\begin{array}{c}1283.56 \pm \\
1366.22\end{array}$ \\
\hline & $\begin{array}{l}\text { Corytophanidae } \\
\text { (B. plumifrons) }\end{array}$ & $10.71 \pm 2.67$ & $44.00 \pm 16.00$ & $18.00 \pm 3.00$ & $2.65 \pm 0.32$ & $1.81 \pm 0.51$ & $0.10 \pm 0.05$ & $\mathrm{ND}$ & $48.30 \pm 26.20$ & $\begin{array}{c}6323.00 \pm \\
2074.00\end{array}$ \\
\hline
\end{tabular}




\section{Table $\mathbf{1}$ (on next page)}

Table 1. Hematological values $(n=40)$ of the Berthold's bush anole (Polychrus gutturosus) in Costa Rica. PCV (Packed cell volume), RBC (Red blood cells), and WBC (White blood cells).

Hematological values ( $n=40$ ) of the Berthold's bush anole (Polychrus gutturosus) in Costa Rica. PCV (Packed cell volume), RBC (Red blood cells), and WBC (White blood cells). 
1 Table 1. Hematological values $(\mathrm{n}=40)$ of the Berthold's bush anole (Polychrus gutturosus) in

2 Costa Rica. PCV (Packed cell volume), RBC (Red blood cells), and WBC (White blood cells).

3

\begin{tabular}{lccc}
\hline \multicolumn{1}{c}{ Analyte (Units) } & Mean \pm SD & Range & 95\% CI \\
\hline PCV $(\%)$ & $31.75 \pm 4.53$ & $23.00-44.00$ & $30.35-33.15$ \\
RBC $\left(10^{12} / \mathrm{L} 9\right.$ & $0.94 \pm 0.20$ & $0.64-1.35$ & $0.88-1.01$ \\
Polychromatophils $(\%)$ & $1.33 \pm 0.69$ & $0.4-3.0$ & $1.11-1.54$ \\
WBC $\left(10^{9} / \mathrm{L}\right)$ & $19.44 \pm 6.66$ & $8.04-37.18$ & $17.38-21.51$ \\
Thrombocyte Count $\left(10^{9} / \mathrm{L}\right)$ & $2.13 \pm 1.14$ & $0.21-4.52$ & $1.78-2.49$ \\
Heterophils $\left(10^{9} / \mathrm{L}\right)$ & $2.66 \pm 1.36$ & $0.84-6.99$ & $2.23-3.08$ \\
Heterophils $(\%)$ & $13.78 \pm 5.14$ & $6.00-29.00$ & $12.18-15.37$ \\
Lymphocytes $\left(10^{9} / \mathrm{L}\right)$ & $14.37 \pm 5.36$ & $5.87-27.14$ & $12.71-16.03$ \\
Lymphocytes $(\%)$ & $74.13 \pm 10.01$ & $26.00-87.00$ & $71.02-77.23$ \\
Monocytes $\left(10^{9} / \mathrm{L}\right)$ & $1.76 \pm 1.71$ & $0.12-10.13$ & $1.22-2.29$ \\
Monocytes $(\%)$ & $8.60 \pm 6.62$ & $1.00-42.00$ & $6.55-10.65$ \\
Eosinophils $\left(10^{9} / \mathrm{L}\right)$ & $0.58 \pm 0.41$ & $0.00-1.57$ & $0.45-0.70$ \\
Eosinophils $(\%)$ & $3.03 \pm 1.79$ & $0.00-7.00$ & $2.47-3.58$ \\
Basophils $\left(10^{9} / \mathrm{L}\right)$ & $0.11 \pm 0.15$ & $0.00-0.45$ & $0.06-0.16$ \\
Basophils $(\%)$ & $0.58 \pm 0.75$ & $0.00-2.00$ & $0.34-0.81$ \\
H:L Ratio & $0.21 \pm 0.17$ & $0.08-1.12$ & $0.15-0.26$ \\
\hline
\end{tabular}

4

5

6 


\section{Table 2 (on next page)}

Table 2. Blood biochemical values $(n=40)$ of the Berthold's bush anole (Polychrus gutturosus) in Costa Rica. A/G Ratio (Albumin/Globulin ratio), AST (Aspartate amino transferase), CK (Creatinin kinase), and Ca:P Ratio (Calcium:Phosphorus rati

Blood biochemical values ( $n=40$ ) of the Berthold's bush anole (Polychrus gutturosus) in Costa Rica. A/G Ratio (Albumin/Globulin ratio), AST (Aspartate amino transferase), CK (Creatinin kinase), and Ca:P Ratio (Calcium:Phosphorus ratio). 
1 Table 2. Blood biochemical values $(n=40)$ of the Berthold's bush anole (Polychrus gutturosus)

2 in Costa Rica. A/G Ratio (Albumin/Globulin ratio), AST (Aspartate amino transferase), CK

3 (Creatinin kinase), and Ca:P Ratio (Calcium:Phosphorus ratio).

4

5

\begin{tabular}{lccc}
\hline \multicolumn{1}{c}{ Analyte (Units) } & Mean \pm SD & Range & $\mathbf{9 5 \% ~ I C ~}$ \\
\hline Glucose $(\mathrm{mmol} / \mathrm{L})$ & $11.96 \pm 2.04$ & $8.38-16.10$ & $11.32-12.59$ \\
Total Protein $(\mathrm{g} / \mathrm{L})$ & $75.10 \pm 7.80$ & $60.00-90.00$ & $72.68-77.52$ \\
Albumin $(\mathrm{g} / \mathrm{L})$ & $17.91 \pm 6.34$ & $3.70-28.17$ & $15.95-19.88$ \\
Globulins $(\mathrm{g} / \mathrm{L})$ & $57.19 \pm 6.20$ & $46.10-70.32$ & $55.27-59.11$ \\
A/G Ratio & $0.32 \pm 0.12$ & $0.06-0.52$ & $0.28-0.36$ \\
AST $(\mathrm{U} / \mathrm{L})$ & $35.08 \pm 23.86$ & $15.10-139.40$ & $27.69-42.47$ \\
CK $(\mathrm{U} / \mathrm{L})$ & $1283.56 \pm 1366.22$ & $122.90-6848.20$ & $860.17-1706.94$ \\
Calcium $(\mathrm{mmol} / \mathrm{L})$ & $3.81 \pm 1.64$ & $2.20-9.35$ & $4.32-3.30$ \\
Phosphorus $(\mathrm{mmol} / \mathrm{L})$ & $2.46 \pm 0.85$ & $1.43-5.49$ & $2.72-2.20$ \\
Ca:P Ratio & $1.60 \pm 0.55$ & $0.76-3.47$ & $1.43-1.77$ \\
Uric acid $(\mu \mathrm{mol} / \mathrm{L})$ & $223.78 \pm 209.56$ & $59.30-1164.90$ & $158.84-288.72$ \\
Cholesterol $(\mathrm{mmol} / \mathrm{L})$ & $8.97 \pm 3.16$ & $4.25-17.50$ & $7.99-9.95$ \\
\hline
\end{tabular}

6 